\title{
Cholin jako esenciální živina a jeho význam v těhotenství
}

\author{
Simona Mlezivová, Pavel Calda \\ Centrum fetální medicíny, Gynekologicko-porodnická klinika 1. lékařské fakulty Univerzity Karlovy a Všeobecné \\ fakultní nemocnice v Praze
}

Během těhotenství a kojení se podobně jako u dalších esenciálních živin zvyšuje poptávka po cholinu. Zároveň se předpokládá, že cholin je důležitý pro neurologický vývoj plodu a novorozence. Cholin je esenciální součástí buněčných membrán. Je to ve vodě rozpustná látka nezbytná pro metabolismus metylové skupiny, syntézu neurotransmiterů, strukturální integritu a signální funkce buněčných membrán. Jako prekurzor neurotransmiteru acetylcholinu může ovlivňovat kognitivní funkce a vývoj mozku. Přímý vztah mezi kognitivními funkcemi dítěte a hladinou cholinu u plodu v děloze byl prokázán ve studiích na zviřatech, ale není dostatečně prokázán u lidí.

U cholinu se předpokládá, že by mohl snižovat hladiny homocysteinu. Vzhledem k tomu, že hyperhomocysteinemie je dávána do souvislosti s rozvojem kardiovaskulárních onemocnění, mohl by tak cholin kardiovaskulárnímu systému prospívat. Všechny tyto informace vedou ke zvýšenému zájmu o získání dostatečné evidence o významu př́imu cholinu v potravě a jeho případnou suplementaci. Těhotenství, kde se rozhoduje nejen o vývoji CNS, v tom může hrát klíčovou roli.

Klíčová slova: cholin, těhotenství, prekoncepce, esenciální živiny.

\section{Úvod}

Cholin je esenciální součástí buněčných membrán. Je to ve vodě rozpustná látka nezbytná pro metabolismus methylové skupiny, syntézu neurotransmiterů, strukturální integritu a signální funkce buněčných membrán (1).

Cholin je prekurzorem neurotransmiteru acetylcholinu, který může ovlivňovat kognitivní funkce a vývoj mozku (2). Během těhotenství a kojení se podobně jako u dalších esenciálních živin zvyšuje poptávka po cholinu (1). Zároveň se předpokládá, že cholin je důležitý pro neurologický vývoj plodu a novorozence $(2,3)$. Prímý vztah mezi kognitivními funkcemi u dětí a hladinou cholinu u plodu v děloze byl prokázán ve studiích na zvíratech (4), ale není dostatečně prokázán u lidí.

Cholin jako prekurzor betainu může zvyšovat remetylaci homocysteinu na methionin (2). Hyperhomocysteinemie je dávána do souvislosti s rozvojem kardiovaskulárních onemocnění. U cholinu se předpokládá, že by mohl hladiny homocysteinu snižovat a prospívat tak kardiovaskulárnímu systému.

Nepodařilo se prokázat pozitivní vliv podávání cholinu u případů pokročilých stadií Alzheimerovy choroby (5). Na druhou stranu se u myší podařilo prokázat pozitivní vliv na výskyt kognitivního deficitu podobného Alzheimerově demenci při dlouhodobém preventivním užívání cholinu (6).

Všechny tyto informace vedou ke zvýšenému zájmu o získání důkazů o významu přímu cholinu v potravě a jeho prípadnou suplementaci. Těhotenství, kde se rozhoduje nejen o vývoji CNS, v tom může hrát klíčovou roli.

\section{Biologické vlastnosti cholinu}

Cholin se do lidského těla dostává potravou nebo je syntetizován de novo biosyntézou z fosfatidylcholinu (FCH) v hepatocytech (7). Betain, derivát cholinu, je navíc hlavním zdrojem metylové skupiny v potravě (8). Cholin je prekurzor fosfatidylcholinu, důležité součásti buněčných membrán, žluče a lipoproteinů. Účastní se také myelinizace neuroaxonů, buněčného dělení a lipidového transportu (9). Cholin hraje důležitou roli v syntéze acetylcholinu, a tím ovlivňuje cholinergní neurotransmisi (10). Může také zlepšovat signalizační procesy, které modulují placentární angiogenezi (11). Protože metabolismus cholinu ovlivňuje řadu biologických procesů, je možné, že jeho nedostatečný př́jem má komplexní vliv na zdraví člověka (12). Ukázalo se, že nedostatek cholinu vede ke snížení plazmatických koncentrací cholinu a FCH, a to i v erytrocytech (13). Cholinová deprivace způsobuje snížené shromažd’ování a vylučování lipoproteinu s velmi nízkou hustotou (VLDL) z jater (14). Mnoho studií prokázalo negativní účinky sníženého přímu cholinu na zdraví, mezi něž patří steatóza jater, nealkoholická steatóza jater (NAFLD), homocysteinémie, poškození svalů (15), zhoršení kognitivních funkcí a karcinogeneze.

Těhotenství a kojení jsou stavy, které vyžadují vyšší př́ijem cholinu kvůli zvýšenému 
buněčnému dělení a membránové syntéze. Pro průkaz předpokládaného vlivu na vývoj mozku plodu a snížení rizika defektů nervové trubice není zatím dostatek solidních dat (16).

\section{Absorpce cholinu}

Cholin je absorbován v horním tenkém střevě pomocí specifických transportérů enterocytů cestou usnadněné difuze (9). Ukázalo se, že proteinový transportér cholinu (Choline Transporter Like-Protein 1 - CTL1) se podílí hlavně na absorpci cholinu v tenkém střevě a jeho funkce závisí na gradientu koncentrace cholinu a na elektrickém membránovém potenciálu. Tento transportér však není tkáňově specifický a je také exprimován v mnoha dalších tkáních. Absorpce cholinu a jeho následný metabolismus závisí na jeho biochemické struktuře. Formy rozpustné ve vodě jsou absorbovány odlišně od forem rozpustných v lipidech.

Fosfatidylcholin $(\mathrm{FCH})$ je téměř úplně absorbován v tenkém střevě $(90 \%)$ a rychle se objevuje $v$ erytrocytech a jako součást lipoproteinů. $\mathrm{FCH}$ je štěpen pankreatickými enzymy, jako je fosfolipáza. Produkty této reakce jsou lysofosfatidylcholin a volné mastné kyseliny, které jsou absorbovány slizničními buňkami a resekretovány $v$ chylomikronech jako nově vytvořený $F C H$ nebo triacylglyceroly. I když doplňky FCH zvyšují koncentraci volného cholinu v séru 8-12 h po podání, neovlivňují koncentraci FCH v séru (17).

V krvi je volný cholin př́tomen v nevázané formè, zatímco esterifikované choliny, jako je $\mathrm{FCH}$, fosfocholin (FChol), sfingomyelin (SGM), jsou složkami lipoproteinů. Průměrná koncentrace cholinu v lidském séru je asi 10 mikromolů (18).

Cholin, který se neabsorbuje, může být metabolizován mikrobioty na trimetylamin (TMA) $(19,20)$ a dále oxidován v játrech na trime-thylamin-N-oxid (TMAO) monooxygenázou 3 obsahující avin. Recentní studie prokázaly silnou pozitivní korelaci mezi zvýšenými koncentracemi TMAO v plazmě a kardiovaskulárními př́hodami, ale mechanismus však nebyl popsán (21-23).

\section{Metabolismus cholinu}

FCH vzniká de novo reakcí katalyzovanou enzymem fosfatidylethanolamin-Nmetyltransferázou (PEMT), která je indukována estrogenem (24). Samice jsou obecně odolnější vůči cholinové deficienci díky vysokým hladinám estrogenu. Během těhotenství mají ženy vysoké koncentrace cholinu a FCH je syntetizován účinněji. Těhotné ženy jsou tedy přirozeně chráněny před cholinovou deficiencí a jsou méně závislé na různých zdrojích cholinu v potravě. Díky tomuto přizpůsobení je k dispozici vyšší koncentrace cholinu během těhotenství a kojení, což je nezbytné pro správný vývoj plodu (25). Zvýšená exprese PEMT u žen však nemusí být dostatečná pro potlačení dietetické cholinové deficience (26). Na myším modelu bylo prokázáno, že exprese PEMT v placentě a fetálních játrech je nízká nebo chybí a většina mateřského cholinu je transportována k plodu pres placentu (27). Postmenopauzální ženy léčené estrogenem mají nižší potřebu cholinu (25), a naopak u žen s nedostatkem estrogenu jsou požadavky na obsah cholinu v dietě vyšší. Muži jsou náchylnější k depleci cholinu, protože mají nízké hladiny estrogenu.

Metabolsmus cholinu úzce souvisí s metabolismem folátu. Snížená dostupnost cholinu zvyšuje poptávku po folátové metylové skupině (28). Protože pro tento proces jsou zapotřebí metylové skupiny pocházející z kyseliny listové, vede nedostatek kyseliny listové ke zvýšení koncentrace $\mathrm{FCH}$ v séru, zatímco doplnění kyseliny listové vede ke zvýšené koncentraci FCH (29).

Prenatální faktory, včetně mateřské stravy, mohou ovlivnit vývoj plodu. Účinky prenatálních spouštěčů lze pozorovat brzy postnatálně, ale také později v životě. Tento proces se nazývá fetální programování a úzce souvisí se zapojením tzv. jednouhlíkového metabolismu $(30,31)$. Zdá se, že epigenetické mechanismy, které regulují genovou expresi a tím ovlivňují fenotyp, mohou být spojením mezi perinatální výživou a metabolismem v dospělosti (32). Bylo prokázáno, že mateřský př́jem folátu a cholinu během těhotenství může vyvolat trvalé modifikace metylačních vzorců u plodu (33-36). Výsledky však nejsou jednoznačné, protože jiné studie vliv na metylaci DNA na deficienci folátu během prenatálního života neprokázaly (37). Byl také testován programovací potenciál celkových dietních omezení. Mohou sice změnit jednouhlíkový metabolismus březích samic, ale nevedou k trvalým metabolickým změnám pozorovatelným u jejich gravidního potomstva (38). Nedostatek potravy během těhotenství může indukovat změny v expresi genů zapojených do modifikace histonů a metylace DNA (39).

\section{Buněčný transport cholinu}

Cholin je pozitivně nabitá molekula, a proto je zapotřebí, aby byl lipidovou membránou přenášen proteinovým mechanismem. Na transportu cholinu přes buněčné membrány se podílejí různé typy proteinů. Byly použity kinetické metody k prokázání dvou typů transportu cholinu: prvním je usnadněná difúze v erytrocytech (40) a přes hematoencefalickou bariéru, druhým aktivní transport v jiných tkáních. Vysoce účinné cholinové transportéry, které jsou závislé na $\mathrm{Na}^{+} \mathrm{a} \mathrm{Cl}$, jsou základními faktory signalizační funkce acetylcholinu v centrálním a periferním nervovém systému. Cholinergní systém reguluje mnoho kognitivních funkcí, jako je pamět, pozornost a procesy učení, ale také reguluje funkce fyziologické jako například kontrakce hladkých a kosterních svalů a modulaci srdeční frekvence $(41,42)$. Syntéza acetylcholinu se vyskytuje ve všech cholinergních neuronech a probíhá přenosem cholinu přes cholinové transportní mechanizmy (CHT) (43). U myší vede genotyp Cht -/- k nehybnosti, nepravidelnému dechu a smrti do hodiny po narození. Na druhé straně, myši Cht +/-, které přežily navzdory nižším množstvím transportérů, byly životaschopné a plodné. Je zajímavé, že vychytávání cholinu u těchto myší bylo na stejné úrovni jako u myší divokého typu (44). Lidský CHT má 5 alelických variant, které jsou spojeny s presynaptickým vrozeným myastenickým syndromem (45). Pacienti s touto poruchou jsou snadno unavitelní a trpí slabostí svalů končetin, očí, obličejových a bulbárních svalů (46). Výskyt této choroby je jeden až dva lidé na 500000 (47). Ve stejném genu CHT vede další delece (1-BP DEL, 1497G) k autozomálně dominantní distální hereditární motorické neuropatii typu VIIA, což je nejčastěji dědičná porucha periferního systému a postihuje jednu osobu z 2500 (48). Mezi klinické přiznaky tohoto onemocnění patříztráta distálních svalů a slabost (49). Všechny tyto príklady naznačuji důležitou roli, kterou hraje transportér $\mathrm{CHT}$ ve vývoji nervového systému.

\section{Placentární transport cholinu}

Protože plod má omezenou schopnost syntetizovat fosfatidylcholin v játrech, je závis- 
lý na přisunu cholinu od matky přes placentu (50). Aktivní transport mezi mateřským a plodovým oběhem zajištují přenašeče cholinu. Cholinové transportéry $v$ placentě nejsou př́liš probádané a není zcela jasné, které transportéry se na přisunu cholinu podílejí.

Role folátových a cholinových transportérů ve vývoji plodu se stále studuje. Alelické varianty genů pro PCFT (protonový folatátový transportér) a CHT mohou vést $\mathrm{k}$ závažným onemocněním. Pro hlodavce může být narušení genů Rfc, Fra a Cht smrtelné. Tyto výsledky naznačují, že role uvedených transportérů je relevantní pro vývoj plodu. Nepodařilo se zatím prokázat souvislost mezi geny kódujícími tyto proteiny a perinatálními výsledky. Počet studií, které měly analyzovat transportéry cholinu a folátu ve vztahu kvývoji plodu, je velmi omezený a přiliš malý na to, aby bylo možné správně posoudit roli těchto transportérů na vývoj plodu a bez dalších studií nelze činit závěry o vlivu transportních genů na stav folátů a cholinu.

\section{Potřeba cholinu v těhotenství}

Bylo prokázáno, že mateřské hladiny cholinu a folátu během těhotenství ovlivňují vývoj plodu $(1,2)$. Doporučená denní dávka (RDA recommended daily allowance) pro přijem folátu v těhotenství je 600 mg ekvivalentů folátu
(51). Navíc se před těhotenstvím a během něj doporučuje suplementace kyselinou listovou. V několika zemích, včetně USA a Kanady, je přidávání kyseliny listové do potravin, jako jsou chléb, těstoviny nebo cereálie, povinné (51). Požadavky na suplementaci cholinem nebyly akceptovány $(21,52)$, ale v roce 1998 Rada pro výživu Národní akademie věd USA cholin uznala poprvé za nezbytnou součást stravy. Současně stanovila doporučení pro přiměřený př́jem cholinu: 7,5 mg na kg tělesné hmotnosti na den. Pro netěhotné bez udání váhy $425 \mathrm{mg} /$ den, pro těhotné $450 \mathrm{mg} / \mathrm{den}$. Pro zajímavost, pro muže stanovila dávku $550 \mathrm{mg} / \mathrm{den}$.

Pro těhotné a kojící ženy byl doporučen vyšší př́jem cholinu, aby byl zaručen jeho dostateč-

\begin{tabular}{|c|c|}
\hline Porce & Cholin (mg/porce) \\
\hline Kuřecí játra, vařená (85 g) & 247 \\
\hline Sojová mouka, odtučněná (128 g) & 201 \\
\hline Losos, uzený (85 g) & 187 \\
\hline Vejce, celé, syrové, čerstvé (1ks) & 125 \\
\hline Kuře, maso s kưží, pečené (85 g) & 56 \\
\hline Mléko (236 ml) & 38 \\
\hline Květák, vařený (64 g) & 24 \\
\hline Fazole (64 g) & 22 \\
\hline Slanina (2 ks) & 20 \\
\hline Mandle (28 g) & 15 \\
\hline Brokolice (64 g) & 15 \\
\hline Ovesné otruby (64 g) & 15 \\
\hline Pekanové ořechy (28 g) & 15 \\
\hline
\end{tabular}

Tab. 2. Nejnižšía nejvyššípodil hlavních zdrojü cholinu na celkovém denním prijjmu cholinu u dospělých žen (55)

\begin{tabular}{|l|c|}
\hline & Dospělé ženy (18-65 let) (\%) \\
\hline Vejce a produkty z vajec & $6,1-18,7$ \\
\hline Ryby, mořské plody & $2,5-10,6$ \\
\hline Obilniny & $9,1-16,5$ \\
\hline Maso a výrobky z masa & $21,6-31,8$ \\
\hline Mléko a mléčné výrobky & $10,8-23,7$ \\
\hline
\end{tabular}

Obr. 1. Těhotné a kojící ženy by měly do jídelničku zařadit potraviny bohaté na cholin (7)

\section{Zdroje v potravě Syntéza v játrech}

Mléko, vejce, maso

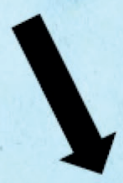

\section{Cholin}

Membrány

Acetylcholin

Donor metylu
Indukce estrogeny

\section{Dítě}

Vrozené vady

Kognice

\section{Matka}

Funkce placenty

Jaterní funkce

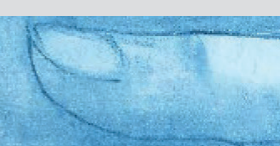


ný prísun vyvíjejícímu se plodu. Ministerstvo zemědělství USA analyzovalo obsah cholinu ve stovkách potravinových produktů a vytvořilo databázi obsahu cholinu v běžných potravinách (53). Nejbohatšími zdroji cholinu jsou vejce, maso a celozrnné obilniny (54).

\section{Souhrn}

Přísun živin k plodu je zásadní pro jeho správný vývoj. Závisí na nutričním stavu matky a přenosu živin od matky k plodu. Během prenatálního vývoje jsou požadavky na přísun cholinu vysoké: plod roste, placenta se zvětšuje, dochází ke zvýšené metylaci DNA a dalším fyziologickým procesům $(1,2,51)$. Dostatečné hladiny cholinu jsou zvláště důležité pro vyvíjející se mozek: je prekurzorem acetylcholinu, klíčového neurotransmiteru pro regulaci proliferace neuronů, diferenciaci, migraci, zrání,

\section{LITERATURA}

1. Greenberg JA, Bell SJ, Guan Y, Yu Y-H. Folic Acid supplementation and pregnancy: more than just neural tube defect prevention. Rev Obstet Gynecol. 2011;4(2):52-59

2. Zeisel SH. Choline: Critical Role During Fetal Development and Dietary Requirements in Adults. Annu Rev Nutr. 2006;26:229-250, doi: 10.1146/ annurev.nutr.26.061505.111156 3. Nazki FH, Sameer AS, Ganaie BA. Folate: Metabolism, genes, polymorphisms and the associated diseases. Gene. 2014:533(1):11-20

4. Masih SP, Plumptre L, Ly A, Berger H, Lausman AY, Croxford $R$, et al. Pregnant Canadian Women Achieve Recommended Intakes of One-Carbon Nutrients through Prenatal Supplementation but the Supplement Composition, Including Choline, Requires Reconsideration. J Nutr. 2015 Aug 1;145(8):182434, doi: 10.3945/jn.115.211300

5. Leermakers ETM, Moreira EM, Kiefte-De Jong JC, Darweesh SKL, Visser T, Voortman T, et al. Effects of choline on health across the life course: a systematic review. Nutr Rev. 2015;73(8):500-22, doi: 10.1093/nutrit/nuv010

6. Gaskins AJ, Rich-Edwards JW, Hauser R, Williams PL, Gillman MW, Ginsburg ES, et al. Maternal prepregnancy folate intake and risk of spontaneous abortion and stillbirth. Obstet Gynecol. 2014;124(1):23-31, doi: 10.1097/ AOG.0000000000000343 7. Zeisel SH. Nutrition in pregnancy: The argument for including a source of choline. Int J Womens Health. 2013;5:193-9, doi: 10.2147/IJWH.S36610

8. Ueland PM, Holm PI, Hustad S. Betaine: A key modulator of one-carbon metabolism and homocysteine status. Clin Chem Lab Med. 2005;43(10):1069-75, doi: 10.1515/CCLM.2005.187 9. Michel V, Yuan Z, Ramsubir S, Bakovic M. Choline Transport for Phospholipid Synthesis. Exp Biol Med. 2006;231(5):490504, doi: 10.1177/153537020623100503

10. Sarter M, Parikh V. Choline transporters, cholinergic transmission and cognition. Nat Rev Neurosci. 2005;6(1):48-56, doi: 10.1038/nrn1588

11. Jiang X, Bar HY, Yan J, Jones S, Brannon PM, West AA, et al. A higher maternal choline intake among third-trimester pregnant women lowers placental and circulating concentrations of the antiangiogenic factor fms-like tyrosine kinasel (sFLT1). FASEB J. 2013 Mar;27(3):1245-53, doi: 10.1096/f.12-221648 12. Cho E, Willett WC, Colditz GA, Fuchs CS, Wu K, Chan AT, et al. Dietary choline and betaine and the risk of distal colorectal adenoma in women. J Natl Cancer Inst. 2007;99(16):1224-31, doi: plasticitu a přežití, ale také pro tvorbu synapsí (3, 21, 52-54). Cholin také poskytuje substrát pro tvorbu fosfatidylcholinu a sfingomyelinu, hlavní složky neuronálních a dalších buněčných membrán potřebných pro přenos signálů, vývoj mozku a růst plodu $(4,6,56)$.

Výsledky některých studií $(9,22,26)$ uvádějí vliv cholinu na hladinu lipidů a kardiovaskulární systém. Jedná se však o výsledky nekonzistentní, s nízkou výpovědní hodnotou a bez kvalitních prospektivních randomizovaných studií. Observační studie naznačují, že cholin může být prospěšný pro neurologické zdraví, zejména pro kognitivní funkce, a pro citlivost na inzulin. Cholin musí být dostupný během kritického období vývoje plodu a dítěte. Pokud tomu tak není, geny, které řídí vývoj mozku a funkci placenty, jsou chybně naprogramovány a může být narušena jejich funkce. To může vést $k$ ab-

normálnímu vývoji mozku, abnormální funkci placenty a preeklampsii (57).

\section{Seznam použitých zkratek}

I $\mathrm{FCH}$ - fosfatidylcholin

- FChol-fosfocholin

- CHT - cholinové transportní mechanismy

- NAFLD - nealkoholická steatóza jater

- PCFT - protonový folatátový transportér (proton-coupled folate transporter)

- PEMT - fosfatidylethanolamin-N-metyltransferáza

- RDA-doporučená denní dávka (recommended daily allowance)

- SGM - sfingomyelin

- TMA - trimetylamin

- TMAO - trimethylamin- $\mathrm{N}$-oxid

- VLDL - lipoprotein s velmi nízkou hustotou (very-low-density lipoprotein)

10.1093/jnci/djm082

13. Zeisel SH. Choline: Human Requirements and Effects on Human Performance. In: Institute of Medicine (US) Committee on Military Nutrition Research, Marriott BM, eds. Food Components to Enhance Performance. Washington (DC): National Academies Press; 1994

14. Yao Z, Vance DE. Reduction in VLDL, but not $H D L$, in plasma of rats deficient in choline. Biochem Cell Biol. 1990;68(2):552-8, doi: 10.1139/090-079

15. Da Costa K-A, Badea M, Fischer LM, Zeisel SH. Elevated serum creatine phosphokinase in choline- deficient humans: mechanistic studies in C2C12 mouse myoblasts. Am J Clin Nutr. 2004;80(1):163-70, doi: 10.1093/ajcn/80.1.163

16. Rees WD, Wilson FA, Maloney CA. Sulfur Amino Acid Metabolism in Pregnancy: The Impact of Methionine in the Maternal Diet. J Nutr. 2006;136(6):1701S-1705S, doi: 10.1093/jn/136.6.17015 17. Buchman AL, Awal M, Jenden D, Roch M, Kang SH. The effect of lecithin supplementation on plasma choline concentrations during a marathon. J Am Coll Nutr. 2000;19(6):76870, doi: 10.1080/07315724.2000.10718076

18. Zeisel SH, Da Costa KA, Franklin PD, Alexander EA, Lamont JT, Sheard NF, et al. Choline, an essential nutrient for humans. FASEB J. 1991 Apr;5(7):2093-8, doi: 10.1096/fasebj.5.7.2010061 19. Romano KA, Vivas El, Amador-Noguez D, Rey FE. Intestinal microbiota composition modulates choline bioavailability from diet and accumulation of the proatherogenic metabolite trimethylamine- N-oxide. MBio. 2015;6(2):e02481-14, doi: 10.1128/mBio.02481-14

20. Zeisel SH, Warrier M. Trimethylamine N-Oxide, the Microbiome, and Heart and Kidney Disease. Annu Rev Nutr. 2017;37(1):157-81, doi: 10.1146/annurev-nutr-071816-064732 21. Wang Y, Surzenko N, Friday WB, Zeisel SH. Maternal dietary intake of choline in mice regulates development of the cerebral cortex in the offspring. FASEB J. 2016 Apr;30(4):156678, doi: 10.1096/f.15-282426

22. Tang WHW, Wang Z, Levison BS, Koeth RA, Britt EB, Fu $X$, et al. Intestinal Microbial Metabolism of Phosphatidylcholine and Cardiovascular Risk. N Engl J Med. 2013 Apr 25;368(17):1575-84, doi: 10.1056/NEJMoa1109400

23. Bae S, Ulrich CM, Neuhouser ML, Malysheva O, Bailey LB, Xiao L, et al. Plasma choline metabolites and colorectal cancer risk in the women's health initiative observational study. Cancer Res. 2014 Dec 15;74(24):7442-52, doi: 10.1158/0008-
5472.CAN-14-1835

24. Resseguie M, Song J, Niculescu MD, Costa K-A, Randall TA, Zeisel SH. Phosphatidylethanolamine N-methyltransferase (PEMT) gene expression is induced by estrogen in human and mouse primary hepatocytes. FASEB J. 2007 Aug;21(10):262232, doi: 10.1096/fj.07-8227com

25. Fischer LM, da Costa K-A, Kwock L, Galanko J, Zeisel SH. Dietary choline requirements of women: effects of estrogen and genetic variation. Am J Clin Nutr. 2010 Nov;92(5):1113-9, doi: 10.3945/ajen.2010.30064

26. da Silva RP, Kelly KB, Lewis ED, Leonard KA, Goruk S, Curtis $J M$, et al. Choline deficiency impairs intestinal lipid metabolism in the lactating rat. J Nutr Biochem. 2015 Oct;26(10):107783, doi: 10.1016/j.jnutbio.2015.04.015

27. Zeisel SH, Mar MH, Zhou Z, da Costa KA. Pregnancy and lactation are associated with diminished concentrations of choline and its metabolites in rat liver. J Nutr. 1995;125(12):3049-54, doi: 10.1093/jn/125.12.3049

28. Kim YI, Miller JW, Da Costa KA, Nadeau M, Smith D, SeIhub J, et al. Severe folate deficiency causes secondary depletion of choline and phosphocholine in rat liver. J Nutr. 1994;124(11):2197-203, doi: 10.1093/jn/124.11.2197

29. Abratte CM, Wang W, Li R, Moriarty DJ, Caudill MA. Folate intake and the MTHFR C677T genotype influence choline status in young Mexican American women. J Nutr Biochem. 2008 Mar;19(3):158- 65, doi: 10.1016/j.jnutbio.2007.02.004 30. Saffery R, Novakovic B. Epigenetics as the mediator of fetal programming of adult onset disease: what is the evidence? Acta Obstet Gynecol Scand. 2014 Nov;93(11):1090-8, doi: 10.1111/aogs.12431

31. Langley-Evans SC, Bellinger L, McMullen S. Animal models of programming: early life influences on appetite and feeding behaviour. Matern Child Nutr. 2005 Jul;1(3):142-8, doi: 10.1111/j. 1740-8709.2005.00015.x

32. Wilkins JF. Genomic imprinting and methylation: Epigenetic canalization and conflict. Trends Genet. 2005;21(6)35665, doi: 10.1016/j. tig.2005.04.005

33. Cooney CA, Dave AA, Wolff GL. Maternal Methyl Supplements in Mice Affect Epigenetic Variation and DNA Methylation of Offspring. J Nutr. 2002;132(8 Suppl):2393S-2400S, doi: 10.1093/jn/132.8.2393S

Další literatura na www.actualgyn.com nebo na vyžádání u autorů. 